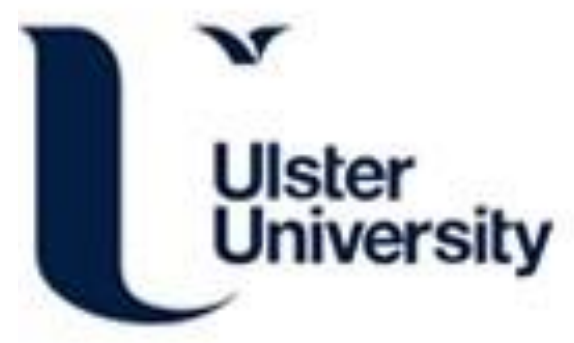

\title{
The genus Geobacillus and hydrocarbon utilization
}

Marchant, R., \& Banat, I. (2010). The genus Geobacillus and hydrocarbon utilization. In KN. Timmis (Ed.), Handbook of Hydrocarbon and Lipid Microbiology (Vol. 3, pp. 1887-1896). Springer. https://doi.org/10.1007/9783-540-77587-4_138

Link to publication record in Ulster University Research Portal

\section{Published in:}

Handbook of Hydrocarbon and Lipid Microbiology

Publication Status:

Published (in print/issue): 01/01/2010

DOI:

10.1007/978-3-540-77587-4_138

\section{Document Version}

Publisher's PDF, also known as Version of record

\section{General rights}

Copyright for the publications made accessible via Ulster University's Research Portal is retained by the author(s) and / or other copyright owners and it is a condition of accessing these publications that users recognise and abide by the legal requirements associated with these rights.

\section{Take down policy}

The Research Portal is Ulster University's institutional repository that provides access to Ulster's research outputs. Every effort has been made to ensure that content in the Research Portal does not infringe any person's rights, or applicable UK laws. If you discover content in the Research Portal that you believe breaches copyright or violates any law, please contact pure-support@ulster.ac.uk. 


\title{
21 The Genus Geobacillus and Hydrocarbon Utilization
}

\author{
R. Marchant . I. M. Banat* \\ School of Biomedical Sciences, University of Ulster, Coleraine, County \\ Londonderry, Northern Ireland, UK \\ *IM.Banat@ulster.ac.uk
}

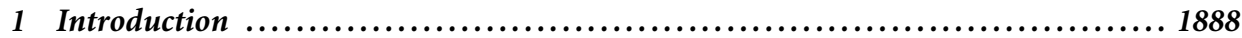

2 The Degradation of Hydrocarbons by Geobacilli ......................... 1889

3 The Molecular Basis of Thermophily ................................... 1891

4 Growth and Survival of Geobacilli Under Different Conditions ............... 1892

5 Distribution and Ecology of Geobacilli ............................... 1894

6 Potential Commercial Exploitation and Research Needs ...................... 1894 
Abstract: The members of the Gram-positive endospore-forming bacteria that made up the genus Bacillus have been gradually subdivided, during the last few years, into a number of new genera such as Alicyclobacillus, Aneuribacillus, Brevibacillus, Gracilibacillus, Paenibacillus, Salibacillus, Ureibacillus, and Virgibacillus. Nazina et al. in 2001 created the genus Geobacillus based around Bacillus (now Geobacillus) stearothermophilus DSM22 as the type strain. The description included two new species of hydrocarbon-oxidizing bacteria isolated from hightemperature oilfields, and the transfer of six members of genetic group 5 thermophilic species of Bacillus to the new genus. Other additions followed and, most of these species, shared the ability to grow at elevated temperatures and degrade hydrocarbons. The taxonomy of geobacilli, hydrocarbon degradation, molecular basis of thermophily, survival, and ecological roles in the environment and possible exploitation potential will be reviewed in this chapter.

\section{Introduction}

The original separation of Bacillus species into various genetic groups based on 16S rRNA gene sequences had been carried out by Ash et al. (1991). The genus Geobacillus was established in 2001 with the following key characteristics: Rod shaped cells producing one endospore per cell; cells may be single or in short chains and may have peritrichous flagella. Cells have a Gram-positive cell wall structure but the gram stain may vary. Chemo-organotrophs, which are aerobic or facultatively anaerobic using oxygen as the terminal electron acceptor, replaced by nitrate in some species. Obligately thermophilic with a growth range of $37-75^{\circ} \mathrm{C}$ and an optimum of $55-65^{\circ} \mathrm{C}$, neutrophilic with a growth range of $\mathrm{pH} 6.0-8.5$. The $\mathrm{G}+\mathrm{C}$ content of DNA is $48.2-58$ mol\% with $16 \mathrm{~S}$ rRNA gene sequence similarity higher than $96.5 \%$ (Nazina et al., 2001).

The original description of the genus had eight species, and a further nine species have been further described or transferred into the genus (Euzéby, 2008). A phylogram showing the relationship of Geobacillus with related genera is shown in $>$ Fig. 1. The majority of these species have been isolated from high-temperature environments e.g., geothermal features or sub-surface layers in high-temperature oil fields. However, these organisms are widely distributed in nature and some isolations have come from cool soil environments, e.g., Geobacillus debilis (Banat et al., 2004), or from hay compost, e.g., Geobacillus toebii (Sung et al., 2002). It is interesting to note that Rhee et al. (2000, 2002) have reported an obligate commensal relationship between $G$. toebii and a Gram-negative thermophilic bacterium Symbiobacterium toebii, which gives one of the few insights into the ecological interactions between geobacilli and other organisms in the environment. A more recent publication (Kim et al., 2008) describes the factors produced by G. toebii which allow S. toebii to grow. These have been identified as a heat- and proteinase-sensitive component of molecular mass $>50 \mathrm{kDa}$ and a heat-stable, proteinase-resistant component of molecular mass $<10 \mathrm{kDa}$. Interestingly, the culture supernatant component seems to induce the type of filamentous growth reported for G. thermoleovorans by Marchant et al. (2002). Kim et al. (2008) have also noted that growth-supporting factors for $S$. toebii are produced by the other bacteria including G. kaustophilus, E. coli, and Bacillus subtilis.

Zeigler (2005) suggested that the predominant use of 16S rRNA gene sequences to differentiate species of Geobacillus may not be the most satisfactory and has carried out a comparison using full-length recN sequences for 68 strains of Geobacillus. From this he 


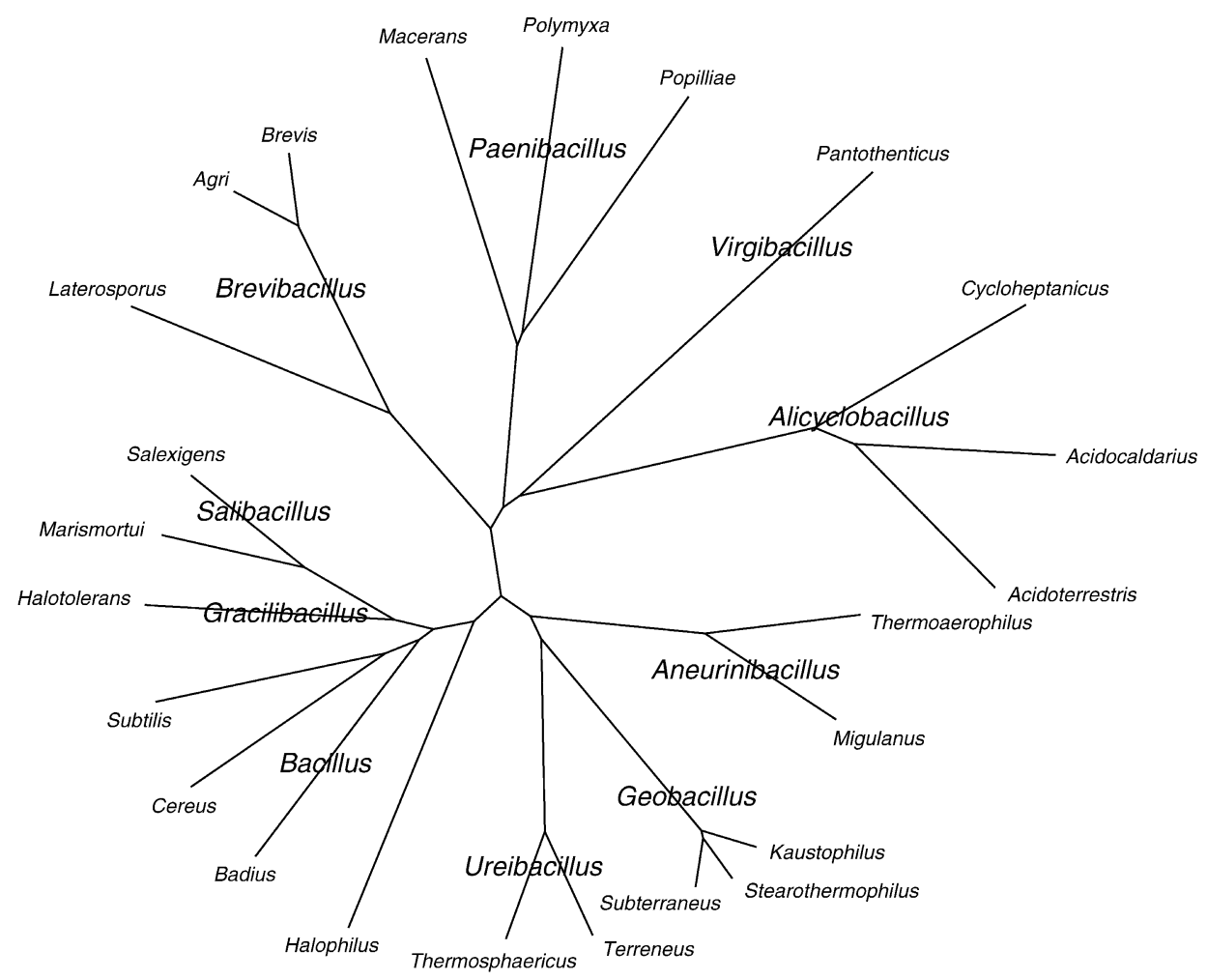

Figure 1

Phylogram showing relationship of Geobacillus with other related genera (reproduced with permission of Dr Daniel R. Zeigler, Bacillus Genetic Stock Center, Ohio State University).

concluded that while 16S rRNA gene sequences provide a satisfactory means of differentiating organisms at higher taxonomic levels $r e c N$ sequence analysis is better at species level.

\section{The Degradation of Hydrocarbons by Geobacilli}

Information about the hydrocarbon-degrading activity of members of the genus Geobacillus is not consistent for each species. The original descriptions of some of the species that were reassigned from Bacillus to Geobacillus did not contain any determination of this character and there has been no subsequent systematic investigation. However, many of the recent species described, have come from oil-rich environments and their capability has been well documented. Thus alkane-degrading activity has been reported for all species except G. thermoglucosidasius, G. tepidamans, G. pallidus and G. lituanicus, with G. debilis reported to have only weak ability (Banat et al., 2004). The absence of information does not necessarily imply the absence of this characteristic but only that it has not been tested for. A full list of currently accepted Geobacillus species (\$ Table 1) can be found on the website of Euzéby (2008). Few studies have examined and reported the range of hydrocarbons utilized by species of 
Table 1

List of accepted species of Geobacillus

\begin{tabular}{|l|}
\hline Geobacillus caldoxylosilyticus \\
\hline Geobacillus debilis \\
\hline Geobacillus gargensis \\
\hline Geobacillus jurassicus \\
\hline Geobacillus kaustophilus \\
\hline Geobacillus lituanicus \\
\hline Geobacillus pallidus \\
\hline Geobacillus stearothermophilus \\
\hline Geobacillus subterraneus \\
\hline Geobacillus tepidamans \\
\hline Geobacillus thermocatenulatus \\
\hline Geobacillus thermodenitrificans \\
\hline Geobacillus thermoglucosidasius \\
\hline Geobacillus thermoleovorans \\
\hline Geobacillus toebii \\
\hline Geobacillus uzenensis \\
\hline Geobacillus vulcani \\
\hline
\end{tabular}

Euzéby (2008)

Geobacillus. Marchant et al. (2002) examined a range of alkanes from pentane to nonadecane, including hexane, heptane, dodecane, hexadecane, and octadecane, and the polyaromatic hydrocarbons naphthalene, anthracene, and kerosene as growth substrates for soil isolates identified as G. caldoxylosilyticus, G. toebii, and G. thermoleovorans. The patterns of utilization were not similar for the different species nor were different strains of $G$. thermoleovorans identical in their ability to use these substrates. Surprisingly there was not even a clear differentiation between the use of short-chain and longer-chain alkanes. No general conclusions can be drawn except that the PAHs are more refractory to degradation. In a recent paper on the genome and proteome of Geobacillus thermodenitrificans NG80-2 Feng et al. (2007) have reported that a plasmid-borne putative monooxygenase gene is responsible for the conversion of $\mathrm{C}_{15}-\mathrm{C}_{36}$ alkanes into the corresponding primary alcohols. The transcription of this gene shows a 120-fold increase when the cells are grown with crude oil as the sole carbon source. The gene has 38\% sequence identity with DBT-5,5'-dioxide monooxygenase of Paenibacillus sp. A11-2 (Ishii et al., 2000) but has no similarity with any known alkane monooxygenase. There has been a study using G. thermoleovorans in a continuous flow fermentation system to degrade phenol at $65^{\circ} \mathrm{C}$ (Feitkenhauer et al., 2003), but no other study of potential alkane degradation at a laboratory scale for possible industrial application has been made. Although the production of biosurfactants by bacteria is often viewed as aiding hydrocarbon degradation, there are no reports of biosurfactant-producing species of Geobacillus and none of the strains that have been grown, shows any evidence of surface-active components.

There have been many studies of the populations of mesophilic bacteria-degrading alkanes and hydrocarbons in contaminated sites. From these studies a number of species of Bacillus 
have been identified that degrade hydrocarbons, e.g., B. subtilis, B. cereus, B. borotolerans (Arvanitis et al., 2008) although in the majority of studies, species of Rhodococcus and Pseudomonas together with other genera predominate.

The genetic basis of alkane degradation has been extensively studied in a number of different bacteria including Pseudomonas putida (van Beilen et al., 2001), Acinetobacter (Ratajczak et al., 1998a, b), and Rhodococcus erythropolis (Whyte et al., 2002). In these organisms the components of the system seem to be organized into two operons, however, in these organisms the enzyme alkane mono-oxygenase catalyzes the first step in the degradative process and there may be at least four alkane mono-oxygenase gene homologues (alkB1alkB4). Marchant et al. (2006) used sequence information from Rhodococcus spp. and Prauserella rugosa to construct degenerate primers to amplify a portion of the alkB gene from $G$. thermoleovorans T80. The aim of this work was to use expression of the alkB gene as a measure of the metabolic activity of geobacilli in cool soil environments. This work clearly showed that over time periods of several weeks, either in laboratory culture or in soil microcosms, no activity was detectable below $40^{\circ} \mathrm{C}$. Since many Geobacillus isolates have come from high temperature oil-containing environments this is not a surprising observation. What is surprising is that large numbers of viable cells of these seemingly obligately thermophilic bacteria can be recovered from environments where the temperature never reaches more than $25^{\circ} \mathrm{C}$.

\section{The Molecular Basis of Thermophily}

There are available four genome sequences for named members of the genus Geobacillus, complete sequences for G. kaustophilus HTA426 (Takami et al., 2004b) and G. thermodenitrificans NG80-2 (Feng et al., 2007), a draft sequence for G. stearothermophilus strain 10 prepared by the University of Oklahoma and available in the public databases, and a draft sequence for G. thermoleovorans T80 (University of Ulster, available in the public databases). The availability of this extensive genomic information for four members of the genus provides an intriguing opportunity to examine the basis for thermophily in these organisms. Geobacilli are closely related to large numbers of mesophilic Gram-positive Bacillus spp. and related genera, and it can be legitimately asked what specific features of the genome and its expression allow growth at high temperatures? A number of possible mechanisms can be postulated that include lateral gene transfer from other thermophilic organisms such as Archaea, specific modification of preexisting mesophile genes and enhanced use of protective mechanisms such as chaperonins. The only material published on the analysis of the Geobacillus genomes is that of Takami et al. (2004a, b) and Feng et al. (2007). Somewhat unexpectedly they found it difficult to identify clear characteristics that could be associated with thermophily, with a large proportion of the genes (1,308 genes representing $37 \%$ of the $3.54 \mathrm{Mb}$ genome) of $G$. kaustophilus shared with all the mesophilic bacilli. A similar situation exists in G. thermoleovorans with many of the genes, particularly those involved in basic metabolic pathways, showing minimal sequence difference from the genes in related mesophilic species (unpublished results), with only small numbers identifiable as orthologs of genes from thermophilic Archaea. One clear feature of these organisms is, however, the presence of large numbers of transposon sequences (55 in G. thermodenitrificans, 80 in G. kaustophilus) in contrast to the low numbers in Bacillus subtilis, B. cereus, and B. anthracis (Feng et al., 2007; Takami et al., 2004b). The presence of these sequences indicates possible high levels of lateral gene transfer 
and active evolution of species still taking place. Examination of the unpublished draft genome sequence for G. thermoleovorans T80 (Matzen et al., unpublished) has revealed the presence of two cassettes of RAMP (Repair Associated Mysterious Proteins) which are not present in the genomes of mesophilic bacilli and which do not appear in the complete genomes of $G$. kaustophilus or G. thermodenitrificans. Further wet-laboratory examination of the genomes of these two organisms indicate that the RAMP cassettes are present but have been eliminated during assembly of the genomes (Matzen et al., unpublished). The recent identification of CRISPRs (clustered regularly interspaced short palindromic repeats) in prokaryotic genomes and their association with 45 CRISPR-Associated (Cas) protein families can explain how the RAMP cassettes (which are now known to be Cas genes) could become eliminated during genome assembly (Haft et al., 2005). Exactly what role the Cas genes play, and whether they have a significant part to play in thermophily remains a matter for conjecture. There is little evidence from the analysis of the Geobacillus genomes carried out so far to support either the view that large numbers of key genes have been laterally transferred from other thermophilic organisms, particularly Archaea, or that base substitution has produced more temperatureresistant versions of preexisting mesophile gene products.

\section{Growth and Survival of Geobacilli Under Different Conditions}

There has been a limited amount of work on the growth and survival of geobacilli, but the majority of papers have ignored this aspect apart from basic characterization of strains. What is clear is that these thermophilic organisms can be easily isolated in a viable state from both hot and cold environments. Standard laboratory experiments carried out over short time periods and using traditional methods to evaluate growth lead to the conclusion that geobacilli show a lower temperature for growth of about $37^{\circ} \mathrm{C}$ and an upper limit of about $70^{\circ} \mathrm{C}$ (Marchant et al., 2002). This pattern fits very well with their distribution in hot environments but singularly fails to explain the large numbers of viable organisms recovered from cool soil environments (Marchant et al., 2002). Rather than asking the question how these organisms are able to grow at elevated temperatures, the question why are they not able to grow at ambient temperatures might be posed, particularly, since the majority of their genome is similar to related mesophilic species. Pavlostathis et al. (2006) undertook a detailed physiological study of G. thermoleovorans T80 using fermentation systems in batch and continuous flow mode, coupled with flow cytometry, to determine the growth and death rates of cells under different conditions. It is clear that these thermophiles growing at temperatures between 60 and $70^{\circ} \mathrm{C}$ show very high growth rates but have correspondingly high death rates. Substrate exhaustion also induces a rapid collapse of the cell population accompanied by extensive cell lysis. This observation is perhaps significant in the light of the report of Rhee et al. (2000) where a commensal relationship was observed between Symbiobacterium toebii and G. toebii involving the requirement for lytic products of the Geobacillus.

One of the key characteristics of the genus Geobacillus is its ability to produce endospores, and in mesophilic bacilli endospores represent a potent survival mechanism under adverse conditions. It is relatively easy to differentiate vegetative cells and spores in mesophilic bacilli through selective killing with heat or chemical agents. This has not proved possible with geobacilli due to the resistance to killing by these agents shown by vegetative cells 
(Marchant et al., 2008). Direct determination of the role of spores in distribution and survival of geobacilli has therefore not yet been determined. An interesting observation has been made concerning the morphology of cells of Geobacillus under certain growth conditions. Marchant et al. (2002) reported the presence of extremely long rods (more than $100 \mu \mathrm{m}$ in length) in cultures of G. thermoleovorans grown at temperatures near the maximum ( $>$ Fig. 2). These cells were not composed of filaments of non-separated cells and showed no evidence of regular division. This suggests that although geobacilli are able to grow at elevated temperatures perhaps not all the metabolic functions of the cells remain perfectly coordinated at the high growth rates achieved.

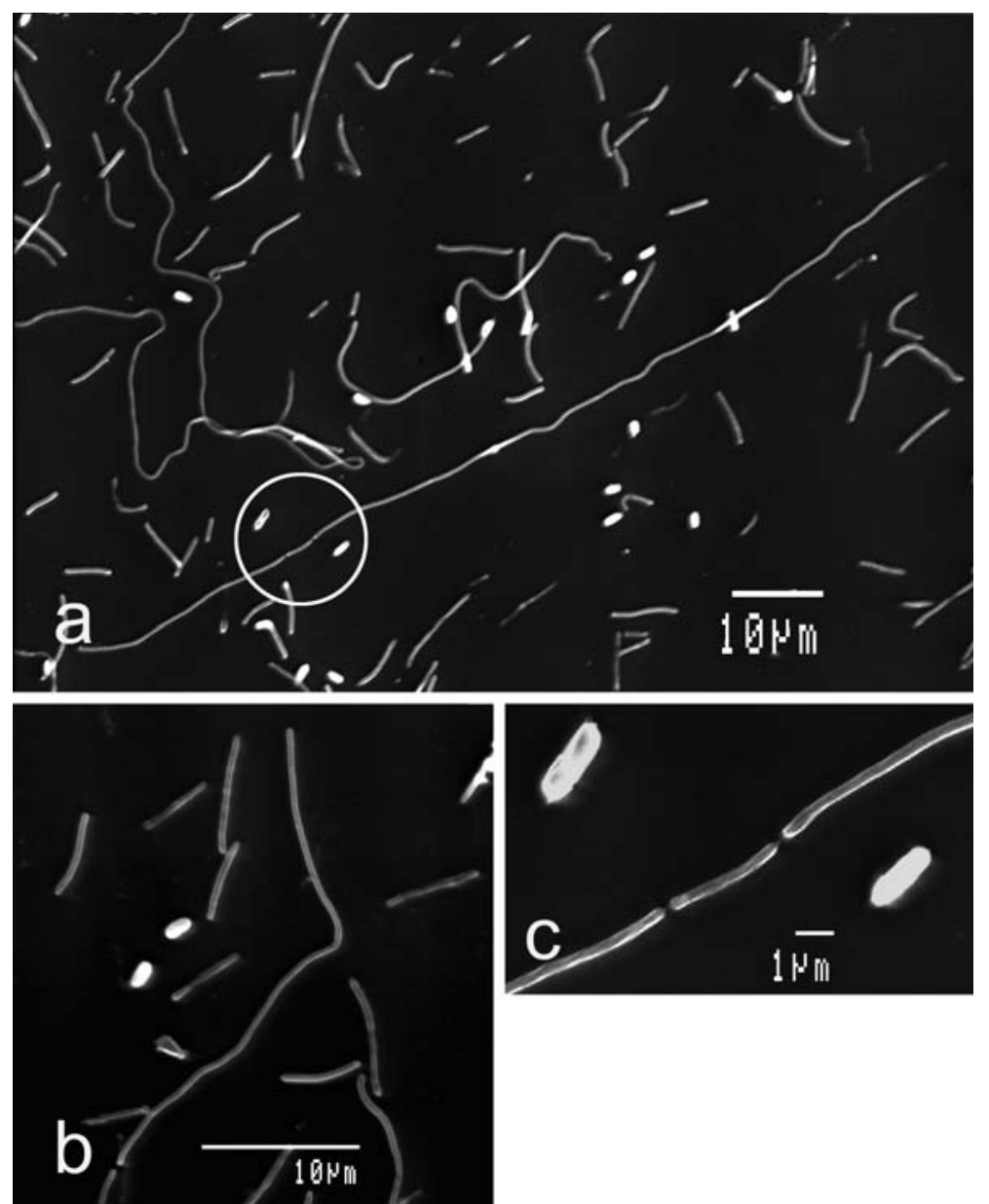

\section{- Figure 2}

Scanning electron micrographs of cells of Geobacillus thermoleovorans strain T80 showing (a) extremely long cells mixed with short and intermediate cells and spores (b) higher magnification image of cells and spores (c) high magnification of region circled in (a) showing two spores and the break-up of a long cell into smaller rods. 


\section{$5 \quad$ Distribution and Ecology of Geobacilli}

One of the major questions that remain concerning bacteria is whether they show biogeographical distribution patterns similar to plants and animals. In a recent review HughesMartiny et al. (2006) drew attention to the concepts of province and habitat, in relation to bacterial distribution where the province represents the legacy of historical events and the habitat the existing environment for the organism. This leads to four possible hypotheses to describe the distribution of bacteria.

1. Microorganisms are randomly distributed over space i.e., only one habitat and one province.

2. Influence of contemporary environmental variation within a single province - the concept that everything is everywhere and the environment selects (Baas-Becking, 1934, cited in Hughes-Martiny et al., 2006).

3. Lingering effects of historical events on one habitat.

4. Microbial distributions shaped by multiple habitats and multiple provinces.

It is not necessarily true that the distribution of all bacteria should be governed by one hypothesis nor that the different hypotheses are mutually exclusive. At first examination it appears that the distribution of geobacilli may fall under hypothesis 3 since they have been extensively isolated from hot environments such as subterranean oil fields which represent habitats surviving from the previous history of the earth. However, the fact that geobacilli can also be isolated from transient "hot environments" e.g., composting plant material (Sung et al., 2002; Wang et al., 2007) and also from permanently cool soil environments (Marchant et al., 2002) points more towards the view of Baas-Becking. The possible basis for sustaining the ubiquitous distribution concept has recently been supported by an investigation of air and rainwater populations of geobacilli (Marchant et al., 2008). In this study it was found that significant numbers of viable geobacilli are deposited in rainwater in Ireland and that the population composition differs from the aerial population indicating that global atmospheric rather than local distribution may be important. Numerous studies have shown the presence of microorganisms in clouds, rainwater and at high altitude (reviewed in Marchant et al., 2008) and furthermore it has been shown that thermophilic bacilli (probably geobacilli) can survive in the extreme conditions of space (Saffary et al., 2002). Thus it can be postulated that geobacilli have a potential worldwide distribution through global atmospheric transport and that they can grow when presented with appropriate environmental conditions. This, however, does not explain completely the high level of viable geobacilli found in cool soil environments down to at least $60 \mathrm{~cm}$ subsurface (Rahman et al., 2004). Although Marchant et al. (2008) have also shown that denitrifying activity in $G$. thermoleovorans is undetectable over a period of several weeks below $40^{\circ} \mathrm{C}$ but rapid at higher temperatures, long term ( 9 month experiments) where G. thermoleovorans was maintained under aerobic conditions at $4^{\circ} \mathrm{C}$ have indicated that extremely slow growth takes place. The current hypothesis is that net growth resulting from the product of growth and death rates is possible at very low levels at ambient soil temperatures. This process therefore can maintain viable soil populations at the levels observed.

Although there has been considerable interest in members of the genus Geobacillus in recent years little of this interest has been directed towards commercial exploitation. The sequence 
databases contain some patented sequences from Geobacillus stearothermophilus and a number of recent publications have been oriented towards thermostable enzyme production particularly amylases and pullulanase. A more interesting application relates to the possible exploitation of the hydrocarbon-degrading capability of geobacilli in soil bioremediation systems (Perfumo et al., 2007). Steam stripping of hydrocarbons from contaminated soils has been used in America for some time and it has been observed that following cessation of steam injection continuing removal of the contaminants takes place during the considerable period of cooling. This ongoing bioremediation takes place through the activity of geobacilli. The main questions to be asked concerning possible use of geobacilli in bioremediation are (1) Is bioaugmentation necessary? (2) Is biostimulation necessary? (3) Do biosurfactants improve remediation? The work of Marchant et al. (2008) has clearly indicated that we may expect Geobacillus species to be already present in most if not all environments therefore bioaugmentation may only be necessary to increase the initial rate of the process. Perfumo et al. (2007) have demonstrated that biostimulation through the addition of inorganic sources of nitrogen and phosphorus can improve the efficacy of the process and in the same way some improvement can be achieved through the use of biosurfactants, particularly the rhamnolipids produced by Pseudomonas. It appears therefore that the hydrocarbon-degrading abilities of geobacilli may find a useful outlet in bioremediation applications in a variety of different situations.

\section{References}

Arvanitis N, Katsifas EA, Chalkou KI, Meintanis C, Karagouni AD (2008) A refinery sludge deposition site: presence of nahH and alkJ genes and crude oil biodegradation ability of bacterial isolates. Biotechnol Lett 30: 2105-2110.

Ash C, Farrow JAE, Wallbanks S, Collins MD (1991) Phylogenetic heterogeneity of the genus Bacillus revealed by comparative analysis of small-subunitribosomal RNA sequences. Lett Appl Microbiol 13: 202-206.

Banat IM, Marchant R, Rahman TJ (2004) Geobacillus debilis sp. nov., a novel obligately thermophilic bacterium isolated from a cool soil environment and reassignment of Bacillus pallidus to Geobacillus pallidus comb. nov. Int J Syst Evol Microbiol 54: 2197-2201.

Euzéby JP (2008) List of prokaryotic names with standing in nomenclature - genus Geobacillus. http:// www.bacterio.cict.fr/g/geobacillus.html (accessed 4 February 2008).

Feitkenhauer H, Schnicke S, Müller R, Märkl H (2003) Kinetic parameters of continuous cultures of Bacillus thermoleovorans sp. A2 degrading phenol at $65^{\circ} \mathrm{C}$. J Biotechnol 103: 129-135.

Feng L, Wang W, Cheng J, Ren Y, Zhao G, Gao C, Tang Y, Liu X, Han W, Peng X, Liu R, Wang L (2007) Genome and proteome of long-chain alkane degrading Geobacillus thermodenitrificans NG80-2 isolated from a deep-subsurface oil reservoir. Proc Natl Acad Sci 104: 5602-5607.

Haft DH, Selengut J, Mongodin EF, Nelson KE (2005) A guild of 45 CRISPR-Associated (Cas) protein families and multiple CRISPR/Cas subtypes exist in prokaryotic genomes. PLoS Comput Biol 1: 474-483.

Hughes-Martiny JB, Bohannan BJM, Brown JH, Colwell RK, Fuhrman JA, Greem JL, Horner-Devine MC, Kane M, Krumins JA, Kuske CR, Morin PJ, Naeem S, Øvreås Reysenbach A-L, Smith VH, Staley JT (2006) Microbial biogeography: putting microorganisms on the map. Nat Rev Microbiol 4: 102-112.

Ishii Y, Konishi J, Okada H, Hirasawa K, Onaka T, Suzuki M (2000) Operon structure and functional analysis of the genes encoding thermophilic desulfurizing enzymes of Paenibacillus sp A11-2. Biochem Biophys Res Comm 270: 81-88.

Kim J-J, Masui R, Kuramitsu S, Seo J-H, Kim K, Sung M-H (2008) Characterization of growth-supporting factors produced by Geobacillus toebii for the commensal thermophile Symbiobacterium toebii. J Microbiol Biotechnol 18: 490-496.

Marchant R, Banat IM, Rahman TJ, Berzano M (2002) The frequency and characteristics of highly thermophilic bacteria in cool soil environments. Environ Microbiol 4: 595-602. 
Marchant R, Franzetti A, Pavlostathis SG, Okutman Tas D, Erdbrügger I, Ünyayar A, Mazmanci MA, Banat IM (2008). Thermophilic bacteria in cool temperate soil environments: are they metabolically active or continually added by global atmospheric transport? Appl Microbiol Biotechnol 5: 841-852.

Marchant R, Sharkey FH, Banat IM, Rahman TJ. Perfumo A (2006) The degradation of $n$-hexadecane in soil by thermophilic geobacilli. FEMS Microbiol Ecol 56: 44-54.

Nazina TN, Tourova TP, Poltaraus AB, Novikova EV, Grigoryan AA, Ivanova AE, Lysenko AM, Petrunyaka VV, Osipov GA, Belyaev SS, Ivanov MV (2001) Taxonomic study of aerobic thermophilic bacilli: descriptions of Geobacillus subterraneus gen. nov., sp. nov. and Geobacillus uzenensis sp. nov. from petroleum reservoirs and transfer of Bacillus stearothermophilus, Bacillus thermocatenulatus, Bacillus thermoleovorans, Bacillus kaustophilus, Bacillus thermoglucosidasius and Bacillus thermodenitrificans to Geobacillus as the new combinations $G$. stearothermophilus, G. thermocatenulatus, G. thermoleovorans, G. kaustophilus, G. thermoglucosidasius and G. thermodenitrificans. Int J Syst Evol Microbiol 51: 433-446.

Pavlostathis SG, Marchant R, Banat IM, Ternan N, McMullan G (2006) High growth rate and substrate exhaustion results in rapid cell death and lysis in the thermophilic bacterium Geobacillus thermoleovorans. Biotech Bioeng 95: 84-95.

Perfumo A, Banat IM, Marchant R, Vezzulli L (2007) Thermally enhanced approaches for bioremediation of hydrocarbon-contaminated soils. Chemosphere 66: 179-184.

Rahman TJ, Marchant R, Banat IM (2004) Distribution and molecular investigation of highly thermophilic bacteria associated with cool soil environments. Biochem Soc Trans 32: 209-213.

Ratajczak A, Geißdörfer W, Hillen W (1998a) Alkane hydroxylase from Acinetobacter sp. Strain ADP-1 is encoded by alkM and belongs to a new family of bacterial integral membrane hydrocarbon hydroxylases. Appl Environ Microbiol 64: 1175-1179.

Ratajczak A, Geißdörfer W, Hillen W (1998b) Expression of the alkane hydroxlase from Acinetobacter sp. strain ADP-1 is induced by a broad range of $\mathrm{n}$-alkanes and requires the transcriptional activator alkR. J Bacteriol 180: 5822-5827.

Rhee SK, Jeon CO, Bae JW, Kim K, Song JJ, Kim JJ, Lee SG, Kim HI, Hong SP, Choi YH, Kim SM, Sung MH
(2002) Characterization of Symbiobacterium toebii, an obligate commensal thermophile isolated from compost. Extremophiles 6: 57-64.

Rhee SK, Lee SG, Hong SP, Choi YH, Park JH, Kim CJ, Sung MH (2000) A novel microbial interaction: obligate commensalism between a new gramnegative thermophile and a thermophilic Bacillus strain. Extremophiles 4: 131-136.

Saffary R, Nandakumar R, Spencer D, Robb FT, Davila JM, Swartz M, Ofman L, Thomas RJ, DiRuggiero J (2002) Microbial survival of space vacuum and extreme ultraviolet irradiation: strain isolation and analysis during a rocket flight. FEMS Microbiol Lett 215: 163-168.

Sung MH, Kim H, Bae JW, Rhee SK, Jeon CO, Kim K, Kim JJ, Hong SP, Lee SG, Yoon JH, Park YH, Baek DH (2002) Geobacillus toebii sp. nov., a novel thermophilic bacterium isolated from hay compost. Int J Syst Evol Microbiol 52: 2251-2255.

Takami H, Nishi S, Lu J, Shinamura S, Takaki Y (2004a) Genomic characterization of thermophilic Geobacillus species isolated from the deepest sea mud of the Mariana Trench. Extremophiles 8: 351-356.

Takami H, Takaki Y, Chee GJ, Nishi S, Shinamura S, Suzuki H, Matsui S, Uchiyama I (2004b) Thermoadaptation trait revealed by the genome sequence of thermophilic Geobacillus kaustophilus. Nucleic Acids Res 32: 6292-6303.

van Beilen JB, Panke S, Lucchini S, Franchini AG, Röthlisberger M, Witholt B (2001) Analysis of Pseudomonas putida alkane degradation gene clusters and flanking insertion sequences: evolution and regulation of the alk-genes. Microbiology 147: 1621-1630.

Wang CM, Shyu CL, Ho SP, Chiou SH (2007) Species diversity and substrate utilization patterns of thermophilic bacterial communities in hot aerobic poultry and cattle manure composts. Microbial Ecol 54: 1-9.

Whyte LG, Smits TH, Labbe D, Witholt B, Greer CW, van Beilen JB (2002) Gene cloning and characterisation of multiple alkane hydroxylase systems in Rhodococcus strains Q15 and NRR1. Appl Environ Microbiol 68: 5933-5942.

Zeigler DR (2005) Application of a $\mathrm{recN}$ sequence similarity analysis to the identification of species within the bacterial genus Geobacillus. Int J Syst Evol Microbiol 55: 1171-1179. 